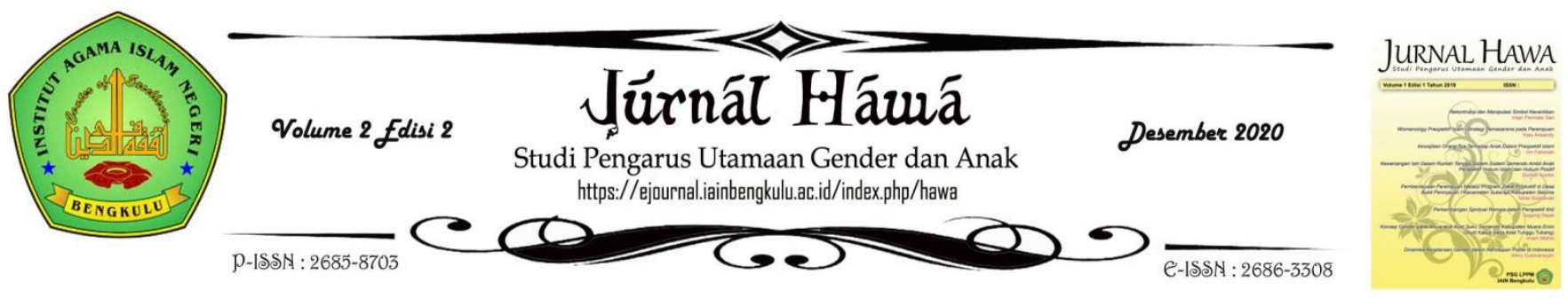

\title{
Perempuan dan Karier: Perbandingan Kesenjangan Upah Gender di Indonesia dengan Megara -Megara Di Eropa (Studi Kasus: Finlandia, Inggris, Praneis, Dan Jerman)
}

\author{
Hartika Arbiyanti \\ Universitas Indonesia \\ hartika.arbiyanti@ui.ac.id
}

\section{Info đrtikel}

Diterima: Oktober

2020

Disetujui: Oktober

2020

Dipublikasikan:

Desember 2020

\section{Keyword}

Gaps, Wages, Gender

Women, Work

\section{Kata \\ Kunci}

Kesenjangan, Upah, Gender, Perempuan, Pekerjaan

\section{Abstract}

In some countries, women's wages lag behind men. The most recent study shows that most of the payments made by gender in wage growth are issued during the first ten years of workers in the labor market. Some part of the contribution of growth can be explained by investment in human capital and work mobility between men and women. In Europe, gender payments occur in several countries. This research will discuss the factors of gender payment in the UK, Finland, Germany, and France - which incidentally relates to gender payments by comparing other countries - with qualitative research methods.
Tbstrak

Dalam beberapa negara, upah perempuan tertinggal dengan laki-laki. Studi terbaru menunjukkan bahwa sebagian besar kesenjangan upah disebabkan oleh perbedaan gender dalam pertumbuhan upah yang terhitung selama sepuluh tahun pertaama pekerja dalam pasar tenaga kerja. Beberapa bagian dari kesenjangan pertumbuhan upah dapat dijelaskan oleh perbedaan dalam investasi modal manusia dan perilaku mobilitas kerja antara laki-laki dan perempuan. Di Eropa, kasus kesenjangan upah gender terjadi di beberapa negara. Penelitian ini akan membahas faktor kesenjangan upah gender dengan di Inggris, Finlandia, Jerman, dan Prancis-yang notabene memiliki reputasi kesenjangan upah gender tertinggi dibandingkan negara eropa lainnya - dengan metode penelitian kualitatif. 


\section{Pendahuluan}

Jika ada perbedaan gender-dalam probabilitas promosi jabatan atau kecenderungan untuk berganti atasan atau majikan-perempuan akan mendapatkan perkembangan upah yang lebih sedikit dibandingkan dengan laki-laki (Napari, 2015). Meskipun demikian, ada peran penting untuk kedua faktor spesifik gender, yaitu perbedaan gender dalam kualifikasi dan perlakuan pasar tenaga kerja, serta struktur upah secara keseluruhan, harga yang ditentukan pasar tenaga kerja untuk keterampilan dan pekerjaan di sektor-sektor tertentu, dalam memengaruhi ukuran kesenjangan upah gender. Perempuan terus menghadapi diskriminasi di pasar tenaga kerja, meskipun nampaknya mulai menurun karena pergerakan serikat buruh. Selain itu, kesenjangan upah juga berpengaruh terhadap keterikatan tenaga kerja perempuan melalui dampak terhadap kekuatan diskriminasi tanggung jawab karena perempuan dianggap masih memegang tanggung jawab utama untuk pekerjaan rumah tangga dan perawatan anak di sebagian besar negara (Kahn, 2000).

Namun, pola ini telah berubah ketika keluarga menanggapi meningkatnya peluang pasar tenaga kerja bagi perempuan yang meningkatkan biaya peluang dari pengaturan semacam itu. Lebih lanjut, kebijakan yang memfasilitasi integrasi tanggung jawab pekerjaan dan keluarga, baik secara sukarela dan yang diamanatkan pemerintah, telah menjadi semakin lazim dalam beberapa tahun terakhir. Pengusaha cenderung untuk terus mengembangkan kebijakan seperti itu ketika mereka merespons perubahan komposisi angkatan kerja dan keinginan untuk mempertahankan karyawan yang telah mereka investasikan secara substansial. Dalam jangka panjang, semakin tersedianya kebijakan semacam itu akan memudahkan perempuan untuk menggabungkan pekerjaan dan keluarga, dan juga bagi lakilaki untuk mengambil bagian yang lebih besar dari tugas-tugas rumah tangga.

\section{Metode Penelitian}

Penelitian ini menggunakan metode penelitian kualitatif untuk memahami fenomena kesenjanan upah gender di Eropa dengan cara mengolah data kuantitatif serta mendeskripsikan tentang faktor-faktor yang memengaruhi kesenjangan upah gender agar dapat dijadikan pertimbangan dalam mengambil suatu keputusan kebijakan terhadap upah gender di Indonesia. selain itu, penelitian ini menggunakan dua teori, yaitu teori gender dari Caroline Moser yang telah dikembangkan menjadi Analisis Model Moser dari disiplin ilmu Antropologi dan teori Makroekonomi dari Keynes yang merupakan dari disiplin ilmu Ekonomi.

Caroline Moser telah mengembangkan teori gender dengan membuat sebuah kerangka yang berdasarkan pada pendekatan Pembangunan dan Gender (Gender and Development/ GAD) dan dibangun pada pendekatan Perempuan dalam Pembangunan (Women in Development/ WID) yang lebih awal dan pada teori-teori feminisme. Dari sekian tujuan kerangka analisis tersebut adalah mengarahkan perhatian kepada pembagian pekerjaan berdasarkan gender yang mempengaruhi kemampuan perempuan untuk berpartisipasi dalam intervensi yang telah direncanakan serta memeriksa dinamika 
kontrol kepada penggunaan sumberdaya antara perempuan dan laki-laki dalam berbagai konteks ekonomi dan budaya yang berbeda-beda (Moser, 2012). Oleh karena itu, tentunya teori ini sangat tepat dalam menjelaskan tentang kesenjangan upah gender di Indonesia.

Dalam teori Makroekonomi Keynes mengatakan bahwa gelombang pasang tampaknya berjalan ke arah lain dengan skeptisisme yang hampir universal terhadap prospek teori upah pekerja. Keynes menolak penjelasan upah ortodoks dengan alasan bahwa fungsi permintaan tenaga kerja didasarkan pada asumsi bahwa tingkat pendapatan diberikan. Hal ini adalah cacat fatal dalam teori, karena setiap perubahan dalam upah uang mampu mengubah pekerjaan dan posisi pendapatan riil, serta pendapatan uang dan tingkat harga. Sejak itu, kecenderungan untuk menganggap tingkat upah uang sebagai variabel yang ditentukan secara eksogen (Weintraub, 1956).

\section{Hasil Penelitian}

Berdasarkan dari hasil penelitian ini, kesenjangan upah gender terjadi tidak hanya di Indonesia tetapi juga di negaranegara Eropa, terutama Jerman, Finlandia, Prancis, dan Inggris. Jumlah tenaga kerja perempuan di dunia terus bertambah. Namun demikian, meskipun perempuan memiliki pangsa besar dalam angkatan kerja, banyak ketimpangan gender di pasar tenaga kerja, seperti pekerjaan khusus gender, ketimpangan upah yang diamati. Perempuan dan laki-laki tidak menerima gaji yang sama untuk pekerjaan yang sama. Diskriminasi upah adalah kenyataan. Rata- rata perempuan memiliki pendapatan yang lebih rendah, upah yang lebih rendah dan persyaratan kerja yang kurang menguntungkan dibandingkan laki-laki.

Oleh karena itu, penyelesaian persoalan kesenjangan upah gender tidak hanya tentang tingkat pekerjaan, pendidikan, inklusi keuangan atau representasi dalam lembaga pemerintahan, tetapi juga tentang kekuasaan pengambilan keputusan dan hubungan interpersonal yang adil serta mentransformasikan hubungan antara laki-laki dan perempuan dalam menggunakan hak yang sama dan berpartisipasi secara relatif setara dengan laki-laki di ruang publik, khususnya dalam kegiatan ekonomi, politik dan masyarakat sipil.

\section{Pembahasan}

Individu sering ditunjuk pada tingkat peringkat tertentu dari skala yang relevan untuk pekerjaan atau industri, yang kemudian bertujuan untuk meningkatkan hierarki. Sementara promosi dan upah tercakup oleh undang-undang antidiskriminasi dan kebijakan peluang yang sama-ada ruang untuk kebijaksanaan-atau diskriminasi-dalam tingkat tertentu. Jadi, jika laki-laki pada awalnya ditunjuk dengan gaji awal yang lebih tinggi dalam skala tertentu daripada perempuan, kesenjangan upah gender mungkin lebih besar ke bagian bawah distribusi. Hipotesis lain adalah bahwa perempuan yang berada di posisi terbawah mungkin memiliki daya tawar yang lebih rendah atau lebih mungkin untuk tunduk pada kekuatan pasar perusahaan daripada laki-laki, mungkin karena keluarga yang 
tidak teramati melakukan komitmen atau kebiasaan sosial di mana karier laki-laki diutamakan (Wiji Arulampalam, 2007).

Sejumlah besar penelitian tentang ketidaksetaraan upah telah memeriksa kekuatan-kekuatan yang dapat menggeser permintaan relatif untuk keterampilan, seperti mengubah pola perdagangan dan perubahan teknis yang bias keterampilan. Namun, karena ekonomi maju beroperasi di lingkungan global yang sama, dengan perdagangan terintegrasi dan akses yang sama ke teknologi, pergeseran permintaan eksogen cenderung serupa di seluruh negara ini; dan di sisi penawaran, proporsi angkatan kerja yang berpendidikan telah meningkat di seluruh ekonomi ini, meskipun sistem pendidikan telah berkembang pada waktu yang berbeda. Oleh karena itu, perbedaan di negaranegara ini dalam evolusi ketimpangan upah tampaknya cenderung mencerminkan, sebagian, variasi spesifik negara dalam cara lembaga pasar tenaga kerja telah berubah (Winfried Koeniger, 2007).

Mengenal Kesenjangan Upah Gender di Finlandia, Inggris, Jerman, dan Prancis

Selama dekade terakhir, fleksibilitas pekerjaan telah dikedepankan sebagai salah satu obat untuk masalah ketenagakerjaan dan ekonomi Uni Eropa dan sebagai salah satu cara untuk mencapai tujuan Uni Eropa mengenai peluang yang setara bagi perempuan dan laki-laki baik, dalam kehidupan pribadi maupun profesional. Meskipun perempuan telah mencapai kesetaraan dalam indikator pembangunan sosial seperti literasi dan Kesehatan, fakta mapan menyatakan bahwa kesetaraan gender belum tercapai di pasar tenaga kerja di dunia internasional, tidak terkecuali di Uni Eropa (Kumari, 2001).

Tabel 1: Kesenjangan Upah Gender Internasional dalam Persentase dari Tahun 1970-2019

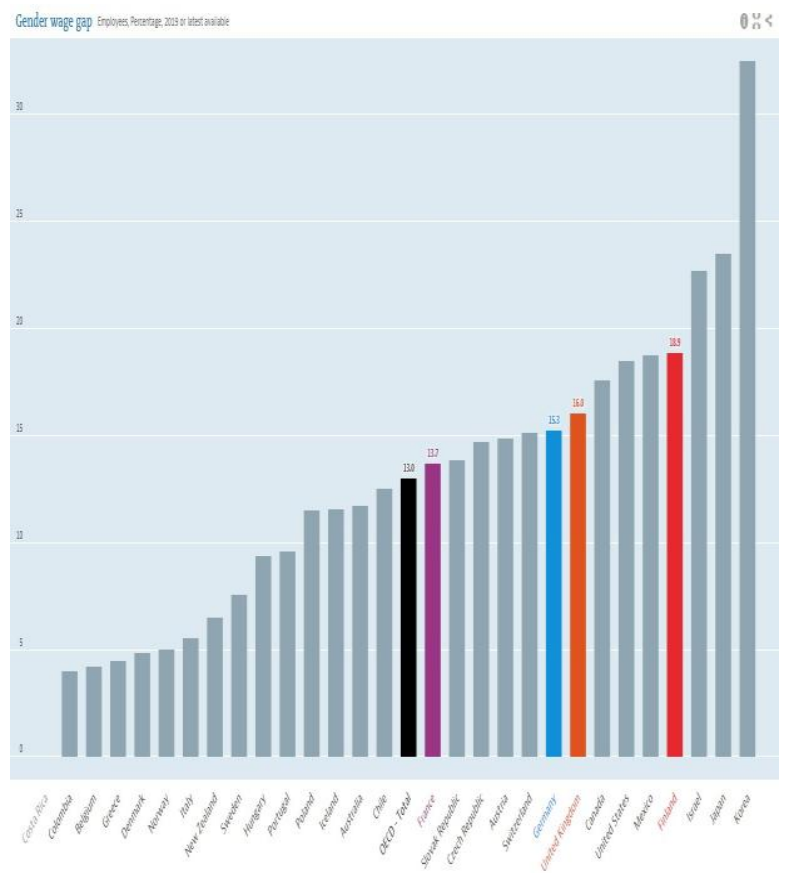

\section{Sumber: OECD}

Meskipun Eropa mengakui kesempatan yang sama bagi laki-laki dan perempuan untuk menjadi jantung reformasi pasar tenaga kerja dan berkomitmen untuk kesetaraan bagi jenis kelamin di tempat kerja-terutama di bawah naungan Uni Eropa, dari diagram di atas menunjukkan bahwa tidak semua negara Eropa memiliki kesetaraan upah gender. Finlandia, contohnya, merupakan negara Eropa yang memiliki persentase kesenjangan upah gender di Eropa tertinggi jika dibandingkan dengan negara Eropa lainnya. Inggris menempati urutan kedua, sementara Jerman menempati urutan ketiga dan Prancis urutan kedelapan. 
Namun, jika kita melihat data ratarata kesenjangan upah gender di antara Finlandia, Inggris, Jerman dan Prancis dalam rentang tahun 2010-2017 seperti diagram tabel yang tercantum di bawah, Inggris merupakan negara di Eropa yang memiliki kesenjangan upah gender lebih besar dibandingkan dengan Finlandia, Prancis, dan Jerman.

Diagram 2. Rata-Rata Kesenjangan Upah Gender di Jerman (DEU), Finlandia (FIN), Prancis (FRA), dan Inggris (GBR)

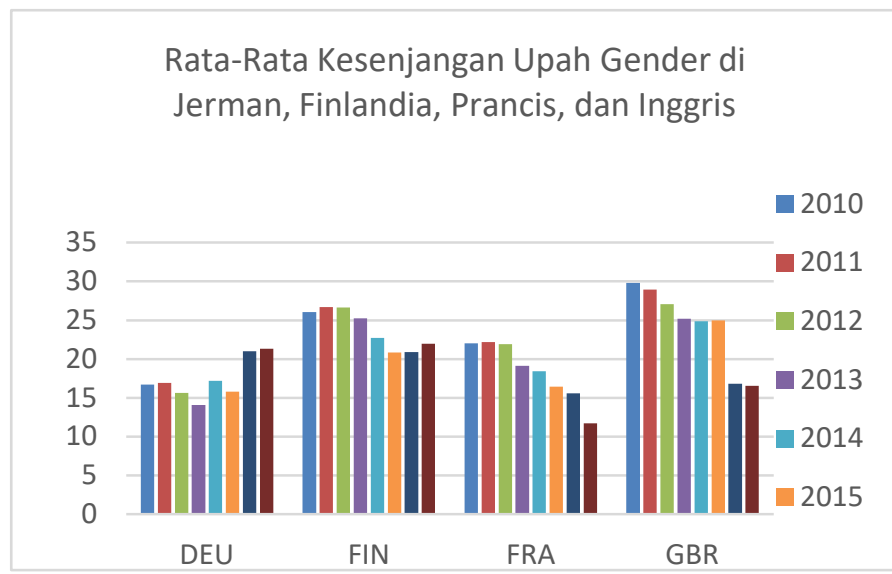

Sumber: OECD (Data diolah oleh penulis).

Di Inggris, kesenjangan upah gender dihitung sebagai perbedaan antara pendapatan rata-rata per jam (tidak termasuk lembur) laki-laki dan perempuan sebagai proporsi dari pendapatan rata-rata per jam (tidak termasuk lembur) dari pendapatan laki-laki (OECD, 2020). Hal ini adalah ukuran di semua pekerjaan di Inggris, bukan dari perbedaan upah antara laki-laki dan perempuan untuk melakukan pekerjaan yang sama. Meskipun demikian, kesenjangan upah gender di Inggris dapat dibedakan antara pekerjaan full-time dengan part-time dengan melihat diagram garis di bawah ini:
Diagram 3. Perbedaan Kesenjangan Upah Gender di Inggris Berdasarkan Jenis Pekerjaan

\section{Perbedaan Kesenjangan Upah Gender di Inggris}

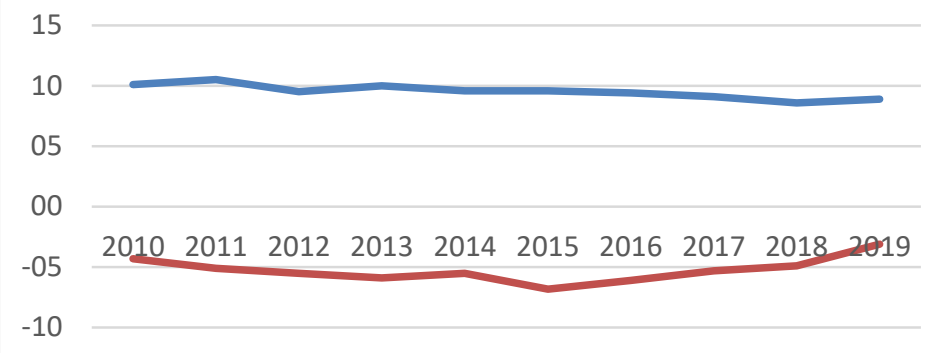

$\longrightarrow$ Full-time Part-time

Sumber:

https://www.ons.gov.uk/employmentandl abourmarket/peopleinwork/earningsandw orkinghours/bulletins/genderpaygapinthe uk/2019. diakses pada 24 Juni 2020 pukul 15.00

Pekerjaan penuh waktu didefinisikan sebagai karyawan yang bekerja lebih dari 30 jam dibayar per minggu (atau 25 jam atau lebih untuk profesi guru), sementara pekerjaan paruh waktu didefinisikan sebagai karyawan yang bekerja kurang dari atau sama dengan 30 jam dibayar per minggu (atau kurang dari atau sama dengan 25 jam untuk profesi guru) di Inggris. Hal ini juga berlaku tidak hanya untuk orang Inggris, tetapi juga immigrant (Miranda, 2018)

Dari diagram garis di atas dapat dilihat bahwa kesenjangan upah gender telah menurun perlahan dalam beberapa tahun terakhir. Di antara karyawan penuh waktu sekarang berada pada 8,9\%, sedikit 
berubah dari 2018 ketika itu 8,6\% (bukan peningkatan yang signifikan secara statistik). Angka untuk 2019 mewakili penurunan 3,3 poin persentase dari satu dekade lalu - 12,2\% pada 2009 - tetapi hanya 0,6 poin persentase sejak 2012. Di antara semua karyawan, kesenjangan turun dari 17,8\% pada 2018 menjadi 17,3\% pada 2019. Kesenjangan upah gender lebih tinggi untuk semua karyawan daripada untuk masing-masing karyawan penuh waktu dan karyawan paruh waktu. Ini karena perempuan mengisi lebih banyak pekerjaan paruh waktu, yang memiliki upah rata-rata per jam lebih rendah daripada pekerjaan penuh waktu, dan lebih cenderung berada di pekerjaan bergaji rendah. Ini dijelaskan lebih lanjut di blog ini, yang ditulis pada tahun 2018.

Selain Inggris, Finlandia termasuk salah satu negara di Eropa yang memiliki kesenjangan upah gender yang tinggi. Menurut laporan dari European Comission, di Finlandia, kesenjangan upah gender adalah 17,3\% (kesenjangan upah gender rata-rata di UE adalah 16,3\%). Kesenjangan pendapatan gender secara keseluruhan adalah perbedaan antara pendapatan tahunan rata-rata antara perempuan dan laki-laki. Hal ini memperhitungkan tiga jenis kerugian yang dihadapi perempuan, yaitu penghasilan per jam yang lebih rendah, bekerja lebih sedikit di pekerjaan yang dibayar, dan tingkat pekerjaan yang lebih rendah (misalnya ketika mengganggu karier untuk mengurus anak-anak atau kerabat). Kesenjangan pendapatan keseluruhan gender di Finlandia mencapai 24,1\% (kesenjangan pendapatan keseluruhan gender rata-rata di UE adalah $39,6 \%)$.
Diagram 4. Perbedaan Kesenjangan Upah Gender di Finlandia Tahun 2010-2018

\section{Kesenjangan Upah Gender di Finlandia}

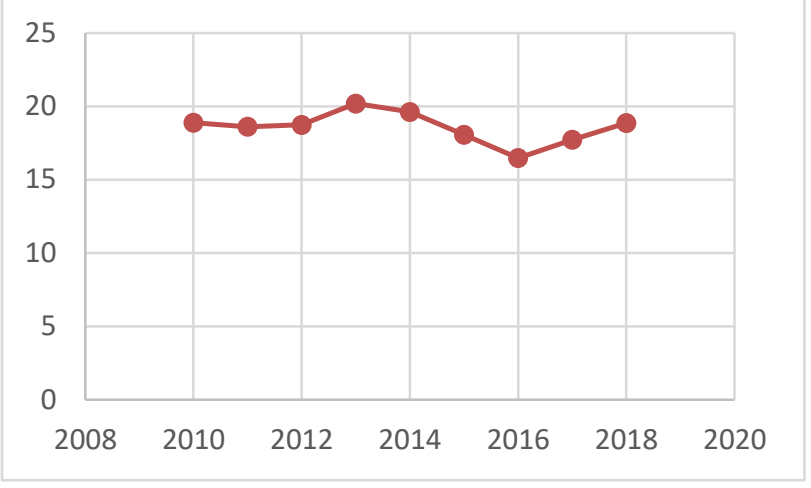

Sumber: World Bank (data diolah oleh penulis)

Dari diagram garis dari data World Bank di atas menunjukkan kesenjangan upah gender cenderung stabil. Hal ini karena kesenjangan upah gender di Finlandia sendiri berawal dari terdapatnya perbedaan pandangan mengenai apakah peningkatan kesetaraan gender akan membuat orang berharap lebih banyak atau lebih sedikit anak. Secara historis, pengaturan keluarga tradisional telah berkorelasi dengan jumlah anak yang lebih tinggi. Selama transisi demografis, perempuan menjadi jauh lebih setara dengan laki-laki. Namun, pada saat yang sama, ketentuan pengasuhan anak menjadi berkurang. Oleh karena itu, mengintensifkan tekanan beban ganda perempuan menggabungkan upah dan pekerjaan rumah tangga sehingga kesenjangan upah gender dimaksudkan agar perempuan lebih banyak menaruh perhatian kepada anak. Ketidakseimbangan antara kesetaraan gender yang tinggi di lembaga-lembaga seperti pendidikan dan 
pekerjaan di pasar dan tingkat keadilan yang lebih rendah dalam kehidupan keluarga telah berkontribusi terhadap rendahnya kesuburan di negara-negara maju (Anneli Miettinen, 2011). Selain itu, mengenai distribusi kesenjangan, hubungan cekung antara tingkat upah dan kesenjangan terdapat korelasi. Kesenjangannya rendah pada tingkat upah yang rendah dan akan meningkat ketika pendapatan yang diharapkan tumbuh.

Jerman juga merupakan salah satu negara yang memiliki kesenjangan upah gender di Eropa setelah Inggris dan Finlandia. Menurut riset yang dilakukan oleh The Economist, upah rata-rata per jam untuk perempuan Jerman adalah $€ 17,09$ (\$ $19,31), 21 \%$ lebih rendah dari laki-laki $€$ 21,60. Hal ini menyesuaikan kebutuhan terhadap sektor, keterampilan, usia sehingga kesenjangan merosot sampai 6$7 \%$. Perempuan lebih disukai daripada lakilaki untuk bekerja dalam pekerjaan layanan dengan bayaran rendah; dua pertiga asisten toko adalah perempuan. Hampir setengah dari perempuan yang bekerja adalah paruh waktu (dibandingkan dengan 9\% laki-laki) dan karenanya cenderung tidak menaiki tangga karier cepat (The Economist, 2020)

Diagram 5. Perbedaan Kesenjangan Upah Gender di Jerman Tahun 2010-2018

\section{Kesenjangan Upah Gender di Jerman}

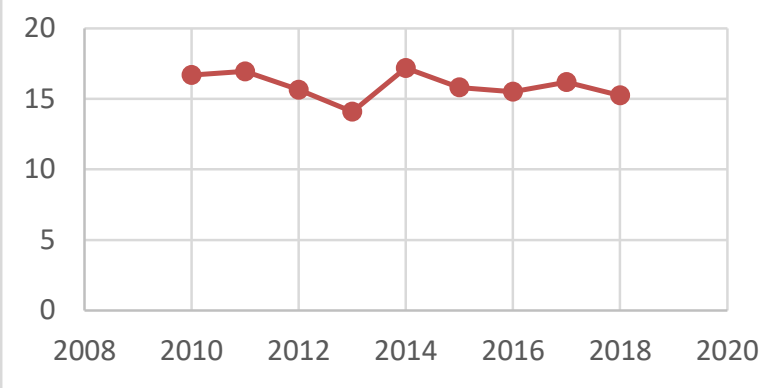

Sumber: World Bank (data diolah oleh penulis)

Dari diagram garis di atas menunjukkan bahwa kesenjangan upah gender di Jerman cenderung stabil, meskipun komposisinya tidak setinggi Inggris dan Finlandia. Ada kemungkinan lembaga-lembaga pasar tenaga kerja bertanggung jawab atas bagian penting dari perbedaan internasional dalam ketidaksetaraan upah-hubungan terbalik antara kesenjangan upah gender yang menunjukkan bahwa mekanisme penetapan upah, seperti yang mencakup perjanjian perundingan bersama yang menyediakan relatif tinggi tingkat upah terhadap laki-laki dibandingkan tingkat upah relatif perempuan yang cenderung berada di bagian bawah distribusi upah. Secara keseluruhan, lembaga penetapan upah memiliki efek penting pada kesenjangan upah gender dan beberapa bukti dampak kekuatan pasar penawaran dan permintaan tenaga kerja di Jerman (Hübler, 2005).

Kesenjangan upah gender juga terjadi di Prancis. Perbedaan dalam upah per jam rata-rata kotor antara laki-laki dan perempuan di seluruh perekonomian cukup signifikan. Di Prancis, kesenjangan upah 
gender adalah 15,8\% (kesenjangan upah gender rata-rata di UE adalah 16,3\%). Dalam hal ini ada tiga jenis yang dihadapi perempuan yang membuat upahnya tidak setara dengan laki-laki, yaitu penghasilan per jam yang lebih rendah, bekerja lebih sedikit jam dalam pekerjaan berbayar, dan tingkat pekerjaan yang lebih rendah, misalnya, ada gangguan dari keluarga, seperti menjaga anak-anak atau kerabat. Meskipun demikian, kesenjangan upah gender secara keseluruhan di Prancis berada pada 31,1\% (kesenjangan pendapatan gender keseluruhan rata-rata di UE adalah 39,6\%).

Diagram 6. Perbedaan Kesenjangan Upah

Gender di Prancis Tahun 2010-2018

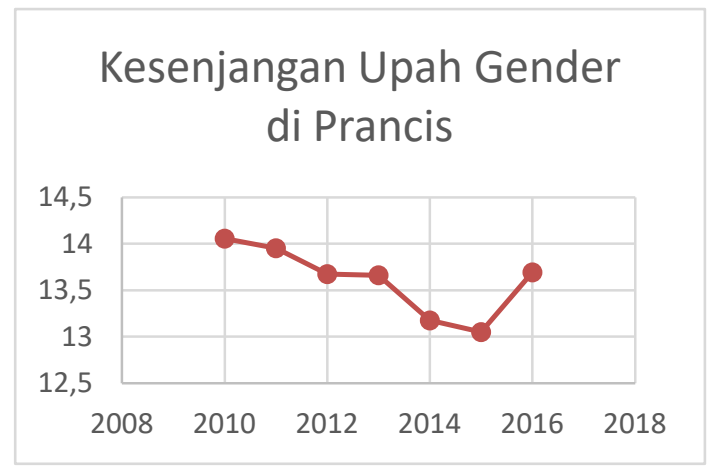

Sumber: World Bank (data diolah oleh penulis)

Dari diagram garis di atas, kesenjangan upah gender di Prancis cenderung fluktuatif. Hal ini disebabkan oleh daya permintaan tenaga kerja (World Bank, 2020). Dalam pekerjaan, posisi manajemen dan pengawasan dipegang oleh laki-laki, bahkan dalam setiap sektor, laki-laki lebih sering dipromosikan daripada perempuan. Tren ini memuncak di bagian paling atas, di mana di antara CEO kurang dari 6\% adalah perempuan. Pendidikan juga mempengaruhi terhadap kesenjangan upah gender di Prancis. Pekerjaan yang sebagian besar dilakukan oleh perempuan, seperti mengajar atau penjualan, menawarkan upah yang lebih rendah daripada pekerjaan yang sebagian besar dilakukan oleh lakilaki, bahkan ketika tingkat pengalaman dan pendidikan yang sama dibutuhkan karena perempuan dianggap mengurangi jam kerja mereka saat bekerja demi mengurus keluarga.

Perbandingan Indonesia dengan Inggris, Finlandia, Jerman, dan Prancis dalam Kasus Kesenjangan Upah Gender

Penelitian tentang kesenjangan upah antargender pada umumnya menggunakan data dari survei ketenagakerjaan dan Badan Pusat Statistik (BPS). Data tersebut kemudian digunakan untuk mengestimasi persamaan upah di antara pekerja laki-laki dan perempuan. Persamaan upah dibagi menjadi dua bagian, explained gap dan unexplained gap. Explained gap merupakan perbedaan upah antara pekerja laki-laki dan perempuan karena perbedaan modal manusia seperti perbedaan pendidikan dan pengalaman kerja, sedangkan unexplained gap atau residual gender wage gap merupakan perbedaan upah antara laki-laki dan perempuan yang tidak dapat dijelaskan oleh perbedaan modal manusia. Dengan menggunakan data tersebut, residual gender wage gap seringkali dianggap sebagai bentuk diskriminasi upah yang dilakukan oleh employer (Martesa Husna Laili, 2019).

Oleh karena itu, 'bekerja atau tidak' merupakan jawaban dari keputusan perempuan jika ditanya tentang keinginannya untuk berpartisipasi dalam pasar tenaga kerja. Upah atau gaji adalah standar untuk mendefinisikan apa yang merupakan hasil dari pekerjaan dalam sebagian besar model ekonomi, tanpa 
melihat perbedaan yang terjadi antara sektor formal dan sektor informal. Meskipun pekerjaan yang mereka lakukan di rumah tidak dianggap sebagai 'kerja' dalam arti ekonomi, tentunya hal itu dapat mempengaruhi keputusan untuk berpartisipasi atau tidaknya berkecimpung dalam pasar tenaga kerja. Pilihan mereka mungkin sebagai berikut: (1) untuk bekerja di rumah tanpa bayaran atau (2) bekerja untuk mendapatkan upah di pasar tenaga kerja-baik dalam sektor formal atau informal. Selain itu, sektor informal memang lebih didominasi oleh perempuan, meskipun sektor informal dianggap sebuah alternatif yang lebih rendah dari sektor formal untuk pekerjaan. Setidaknya bagi perempuan, hal itu menunjukkan model yang lebih tepat dari keputusan yang akan diambilnya. (Bernasek, 2002).

Selain negara Inggris, Finlandia, Jerman, dan Prancis, Indonesia juga memiliki kesenjangan upah gender. Meskipun ketimpangan gender masih ada dan terjadi di Indonesia, ketimpangannya semakin berkurang. Hal ini tentu menjelaskan bahwa kesempatan perempuan dan laki-laki di Indonesia makin hari makin sama. Demikian pula halnya dalam bidang ketenagakerjaan, peran perempuan dalam ketenagakerjaan semakin luas dan membuka peluang kesempatan untuk mengembangkan potensinya. Kesempatan yang sama dan perlakuan yang sama di pasar tenaga kerja merupakan inti dari pekerjaan yang layak. Sayangnya, kebanyakan perempuan di seluruh dunia, bahkan di Indonesia, masih menghadapi kendala tambahan untuk mengakses pekerjaan, dan sekali dalam pekerjaan, kesulitan untuk mengakses posisi pengambilan keputusan dan pekerjaan di sektor tertentu atau dengan karakteristik tertentu. Pemisahan gender pekerjaan dikombinasikan dengan distribusi pekerjaan tidak berbayar yang tidak setara (termasuk kegiatan rumah tangga dan pengasuhan anak), menghasilkan perbedaan dalam kondisi kerja seperti kesenjangan upah berdasarkan gender dan representasi perempuan yang berlebihan dalam pekerjaan paruh waktu (International Labour Organization, 2020). Diagram 7. Tenaga Kerja di Indonesia 19952019

\section{Total Tenaga Kerja di Indonesia}

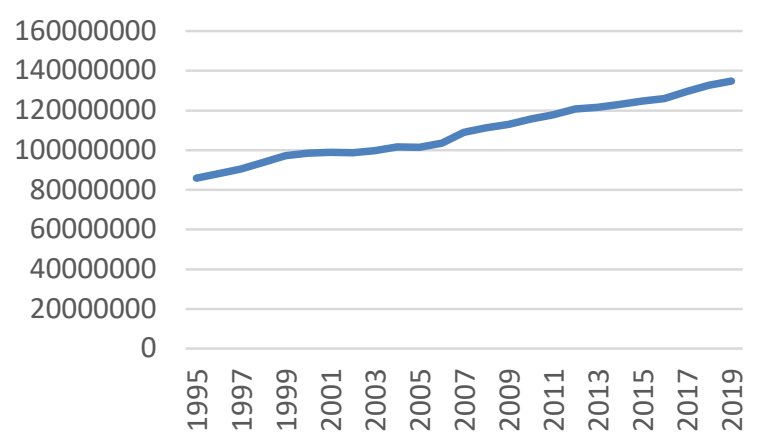

Sumber: World Bank (data diolah oleh penulis)

Dari data di atas dapat diambil kesimpulan bahwa tenaga kerja di Indonesia semakin meningkat dalam kurun waktu 24 tahun yang diiringi dengan kenaikan jumlah penduduk. Globalisasi dapat memberikan hasil positif dan negatif, tetapi Indonesia harus melanjutkan reformasinya untuk mendapatkan hasil maksimal dari keterlibatannya dengan seluruh dunia. Dalam hal ini, perbaikan mekanisme kompensasi dan peningkatan fleksibilitas pasar tenaga kerja adalah kunci 
untuk mengurangi risiko dan biaya globalisasi. Pasar tenaga kerja dapat menyesuaikan dengan berbagai margin sebagai respons terhadap kenaikan upah minimum. Misalnya, pemberi kerja dapat mengubah jumlah pekerja yang dipekerjakan di suatu perusahaan, atau mereka dapat menyesuaikan jumlah ratarata jam kerja setiap pekerja. Selain itu, perusahaan dapat mengubah campuran pekerja yang dipekerjakan setelah kenaikan upah minimum, yang pada dasarnya mencoba menyelaraskan kembali produk marjinal pekerja mereka dengan upah yang mereka terima. Akibat dari penyesuaian ini, pengaruh upah minimum dapat melampaui pekerja yang upahnya secara langsung dipengaruhi oleh lantai yang lebih tinggi (David Neumark, 2004).

Penelitian dari LIPI yang menggunakan data dari Sakernas tahun 1996, 1999, 2002, dan 2004 serta metode dekomposisi Oaxaca-Blinder telah menunjukkan bahwa faktor penyebab kesenjangan pendapatan antargender adalah sekitar $41,6 \%$ yang disebabkan oleh perbedaan karakteristik dan sekitar 58,4\% disebabkan oleh faktor tidak dijelaskan (unexplained). Hal ini menjelaskan bahwa sebagian besar kesenjangan upah di Indonesia disebabkan oleh faktor yang tidak dapat dijelaskan (unexplained) dan diindikasikan sebagai sebuah diskriminasi. Tentunya, salah satu konsekuensi potensial dari tren terbaru dalam upaya ketahanan yang berfokus pada gender mungkin norma gender yang diskriminatif sebenarnya diperkuat. Ketidaksetaraan ini sebagian besar berkenaan dengan potensi pengorbanan yang dilakukan perempuan sebagai pengasuh utama keluarga dan rumah, yang harus diakui oleh program adaptasi perubahan iklim dalam menciptakan strategi berbasis rumahan (Hennigusnia, 2014).

Dekomposisi kesenjangan upah berdasarkan gender ini menawarkan beberapa manfaat. Pertama, mengidentifikasi bagian dari kesenjangan upah gender yang dapat dijelaskan oleh karakteristik pasar tenaga kerja dapat membantu pembuat kebijakan dalam merancang kebijakan yang menargetkan perbedaan dalam karakteristik antara perempuan dan laki-laki, misalnya, dengan mengurangi perbedaan dalam pencapaian pendidikan atau dengan mendorong perempuan dan laki-laki untuk melakukan diversifikasi lintas pekerjaan atau sektor. Kedua, jika ukuran komponen yang tidak dapat dijelaskan itu besar, hal ini mungkin menunjukkan bahwa mengurangi kesenjangan upah gender juga membutuhkan langkah-langkah untuk menghapus diskriminasi upah dan mempromosikan kerangka hukum dan kebijakan yang kondusif untuk upah yang sama untuk pekerjaan dengan nilai yang sama antara perempuan dan laki-laki (International Labour Organization, 2018).

Pasar tenaga kerja juga memiliki prioritas gender yang tercermin dalam ekspektasi berbasis gender tentang jenis pekerjaan yang sesuai untuk laki-laki dan perempuan muda serta kepadatan laki-laki dan perempuan dalam pekerjaan tertentu. Contohnya, seiring dengan pergeseran perekonomian industri berat dan manufaktur ke pekerjaan perdagangan dan jasa, peluang kerja baru bagi perempuan muda telah terbuka, misalnya sebagai SPG di mal dan profesi lain di sektor 
perdagangan dan jasa. Mayoritas laki-laki juga mendapatkan pekerjaan di industri manufaktur berat, transportasi, dan perdagangan; sebagian besar perempuan bekerja di perdagangan, jasa, dan industri manufaktur ringan. Sementara profesi tertentu dapat diambil oleh laki-laki dan perempuan sebagai bagian lain dari pasar tenaga kerja yang mencerminkan pembagian gender ke dalam pekerjaan lakilaki (dalam transportasi, konstruksi, industri berat) dan pekerjaan perempuan (sebagai pedagang, staf di toko, perawat, guru, dan pekerja pabrik di industri manufaktur ringan) (Naafs, 2013).

Dalam hal sektor jasa, Tenaga Kerja Wanita (TKW) juga menjadi pilihan perempuan dalam upaya mendapatkan pendapatan. Bahkan, kebijakan pemerintah Indonesia hingga tahun 2009 juga mendorong ekspor TKW mengikuti praktik zaman kolonial dan pascakolonial untuk mengurangi pengangguran dan mengurangi risiko keresahan sosial. Pemikiran pemerintah juga mencerminkan kebijakan Bank Dunia dan mulai memberikan izin kepada perusahaan swasta untuk merekrut dan mengekspor pekerja serta membentuk Biro Ekspor Tenaga Kerja dan menetapkan target untuk mengirim lebih banyak pekerja perempuan ke luar negeri karena menyadari potensi remitansi pada tahun 1990-an. Pada tahun 2009, nilai remitansi telah mencapai 6,6 miliar dolar AS-dengan pekerja rumah tangga yang merupakan $77 \%$ dari angkatan kerja migran Indonesia-memberikan kontribusi terbesar bagi devisa negara (Austin, 2017).
Selain itu, kontribusi perbedaan upah gender dalam tingkat pekerjaan sektor formal setelah pekerjaan dan perbedaan tingkat individu, terhadap perbedaan gender dalam pendapatan yang tercatat. Intinya, ini mengkaji apa yang akan terjadi jika distribusi pendidikan / pekerjaan dan struktur gaji tetap dipertahankan, dan perempuan dipekerjakan di sektor publik dalam proporsi yang sama dengan laki-laki (Jacobs, 1998). BPS juga menyebutkan kesenjangan upah ini merupakan isu yang lama karena adanya anggapan perempuan kurang berkontribusi dalam pekerjaan. Selain itu, perempuan memiliki kecenderungan yang lebih besar untuk dikategorikan sebagai bukan angkatan kerja karena biasanya menghasilkan produk yang dikonsumsi oleh rumah tangganya sendiri. Pekerjaan rumah tangga yang seringkali menjadi tugas perempuan, memengaruhi ketersediaan seseorang untuk bekerja. Selain itu, perempuan juga cenderung ditempatkan pada posisi yang bernilai rendah. Masalah ini menjadi tantangan bagi perempuan dalam dunia ketenagakerjaan untuk mendapatkan pekerjaan, pendapatan, dan posisi kepemimpinan yang setara .

Namun, analisis kesenjangan gaji harus ditempatkan dalam konteks yang lebih luas dari dimensi lain dari ketidaksetaraan antara perempuan dan lakilaki, termasuk akses perempuan yang lebih terbatas ke pekerjaan berbayar dan pembagian tugas yang tidak setara dalam rumah tangga. Di negara berpenghasilan tinggi, partisipasi perempuan dalam pekerjaan berbayar telah meningkat pesat selama beberapa dekade terakhir, hampir setara dengan laki-laki di beberapa negara. 
Namun hal ini tidak terjadi di sebagian besar negara berkembang (Mendoze, 2017). Secara global, perempuan masih jauh lebih kecil kemungkinannya dibandingkan lakilaki untuk berpartisipasi dalam pasar tenaga kerja.

Tingkat pengangguran atau Unemployment Rate juga merupakan salah satu indikator untuk membaca seberapa besar perempuan berkategori angkatan kerja yang menjadi pengangguran. Hal ini juga merupakan indikator yang umum digunakan untuk menjelaskan situasi pasar tenaga kerja dan didefinisikan sebagai persentase jumlah pengangguran terhadap jumlah angkatan kerja. Dalam mengetahui perbedaan tingkat pengangguran antara laki-laki dan perempuan dapat dijelaskan melalui tabel di bawah ini:

Diagram 8. Tingkat Pengangguran di Indonesia Tahun 1995-2019

\section{Tingkat Pengangguran di Indonesia} (Estimasi ILO)

15

10

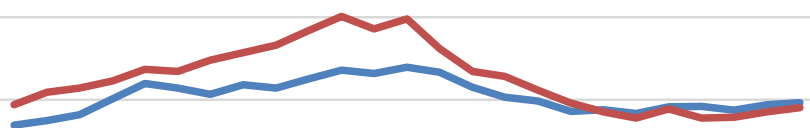

1995199719992001200320052007200920112013201520172019

Sumber: World Bank (data diolah oleh penulis)

Tabel di atas menjelaskan bahwa tingkat pengangguran terhadap perempuan dalam rentang tahun 1995-2019 semakin menurun. Tentunya, hal ini membuktikan bahwa perempuan di Indonesia cenderung berkeinginan untuk berproduktif dalam bekerja dibandingkan memilih keputusan untuk tidak bekerja. Akan tetapi, tingkat pengangguran yang terjadi secara umum sebenarnya dipengaruhi oleh kurangnya pekerja dengan keterampilan yang tepat untuk pekerjaan yang ditawarkan telah tercermin dalam sejumlah masalah pasar tenaga kerja yang endemik di Indonesia, termasuk tingkat produktivitas yang rendah dan tingkat pengangguran kaum muda yang tinggi. Akibatnya, upaya "sisi penawaran" untuk meningkatkan produktivitas-melalui investasi dalam pendidikan dan pelatihan-telah menjadi tujuan pemerintah berturut-turut sejak era Soeharto.

Selain itu, faktor politik juga mempengaruhi tingkat pengangguran di Indonesia. Elit yang korup telah membiarkan orang asing mengeksploitasi tanah, tenaga kerja dan sumber daya Indonesia serta membuat pengelolaan ekonomi yang sehat menjadi lebih terdesak karena krisis ekonomi dan inflasi yang tinggi telah memicu ledakan kekerasan yang bermuatan rasial dan semakin banyaknya pengangguran. Meskipun sudah terdapat inisiatif pengampunan pajak dan serangkaian paket deregulasi untuk berupaya meningkatkan pendapatan dan investasi swasta untuk membantu mempertahankan ledakan infrastruktur dan memotivasi pertumbuhan ekonomi yang lebih tinggi, transportasi dan infrastruktur jalan yang menua membuat Indonesia tidak keluar dari jebakan kecilnya pendapatan atau upah, bahkan tidak terlepas dari naiknya tingkat pengangguran (Warburton, 2018).

Oleh karena itu, selain memperhatikan transportasi dan 
infrastruktur, Pemerintah Indonesia saat ini juga lebih menekankan pada peningkatan produktivitas melalui perolehan keterampilan daripada para pendahulunya pada periode pasca-Soeharto. Padahal, Rencana Pembangunan Jangka Menengah Nasional (RPJMN) 2015-19, yang ditetapkan prioritas pemerintah saat ini memiliki fokus yang kuat untuk meningkatkan produktivitas tenaga kerja dan menciptakan lapangan pekerjaan. Namun hingga saat ini, fokusnya terus berlanjut pada perluasan jumlah pendaftaran dan kuantitas pekerjaan daripada kualitasnya. Selain itu, selama investasi dalam pendidikan, terutama keterampilan menjadi prioritas, kualitas sekolah kejuruan telah menjadi perhatian serius terkait dengan kurikulum yang ketinggalan zaman, kekurangan guru yang berkualitas dan kegagalan untuk menghubungkan upaya di sisi penawaran dengan kebutuhan bisnis. Terakhir, perusahaan swasta cenderung kurang berinvestasi dalam pelatihan pekerja (Pratomo, 2018). Dalam hal ini, perempuan mendapatkan perhatian khusus untuk menempuh pendidikan dan keterampilan karena akan menjadi daya tawar dalam pasar tenaga kerja sehingga kesenjangan upah akan menjadi relatif kecil (Dan A. Black, 2008).

Dengan latar belakang tersebut, terkait ketenagakerjaan, seharusnya lebih ditekankan pada menaikkan kualitas lapangan kerja sehingga diharapkan dapat mengurangi tingkat pengangguran. Intinya, hal ini tentang bagaimana caranya untuk mencapai pekerjaan layak untuk semua, yang sejalan dengan kampanye global
Organisasi Buruh Internasional (ILO) tentang pekerjaan layak. Menurut ILO, pekerjaan yang layak melibatkan peluang untuk pekerjaan yang penuh dan produktif, menghormati perjuangan pekerja, memberikan kebebasan kepada orangorang, dan memberi pekerja keamanan dan perlindungan sosial (International Labour Organization, 2020).

Kelayakan atau tidaknya pekerjaan juga harus diperhatikan oleh pemerintah. Sejauh ini, beberapa perekonomian sektor informal memiliki karakteristik pendapatan atau upah yang lebih rendah (karena ukuran perekonomian informal berkorelasi positif dengan tingkat kemiskinan) serta kurangnya keberlanjutan pendapatan, jaminan kerja dan perlindungan sosial, seperti dalam kasus pekerja rumah tangga perempuan dan pekerja anak. Pekerjaan dengan karakteristik seperti itu tidak layak. Tidak hanya itu, tidak semua sektor formal dapat dikategorikan layak, terutama karena rendahnya kepatuhan terhadap peraturan ketenagakerjaan. Oleh karena itu, penting bagi pemerintah untuk berupaya meningkatkan kualitas lapangan pekerjaan dengan upah dan jaminan layak untuk semua gender agar dapat menurunkan tingkat pengangguran di Indonesia (Tadjoeddin, 2014).

Pada kesimpulannya, permasalahan perbedaan upah gender tidak hanya terjadi di Indonesia, tetapi juga di negara Eropa, terutama Finlandia, Inggris, Prancis, dan Jerman yang merupakan negara maju. Lakilaki dan perempuan tidak menerima gaji yang sama untuk pekerjaan yang sama. Oleh karena itu, diskriminasi upah tidak terbantahkan. Secara umum, perempuan 
memiliki pendapatan lebih rendah, upah lebih rendah, serta persyaratan kerja yang kurang menguntungkan dibandingkan lakilaki. Namun, secara khusus, perbedaan gaji laki-laki dan perempuan ternyata mempengaruhi posisi perempuan di pasar tenaga kerja dan perannya dalam rumah tangga. Perempuan yang dibayar upah dan tunjangan jaminan sosial rendah akan menyebabkan pembayaran pensiun yang juga lebih rendah. Ketimpangan tersebut juga menentukan konsekuensi negatif lainnya. Tingkat upah yang lebih rendah bagi perempuan dapat meningkatkan tingkat pengangguran,s karena perempuan cenderung menggantungkan perekonomian pada pasangan laki-laki sehingga dapat meningkatkan kerentanan terhadap kekerasan dalam rumah tangga dan meningkatnya angka perceraian. Oleh karena itu, pemerintah seharusnya menyelesaikan masalah ketimpangan upah gender dengan membuat kebijakan kesetaraan upah gender di berbagai sektor serta perlindungan terhadap perempuan, dan mempermudah akses pendidikan tinggi kepada perempuan agar dapat menekan angka pengangguran di Indonesia.

\section{Daftar Pustaka}

Anneli Miettinen, S. B. (2011). Gender equality and fertility intentions revisited: Evidence from Finland. Demographic Research, 469-496.

Austin, M. (2017). Defending Indonesia's Migrant Domestic Workers. In H. S. Ward Berenschot, Citizenship and Democratization in Southeast Asia (pp. 265-287). Brill.
Bernasek, J. H. (2002). Gender and Informal Sector Employment in Indonesia. Journal of Economic Issues, 313-321.

Dan A. Black, A. M. (2008). Gender Wage Disparities among the Highly Educated. The Journal of Human Resources, 630-659.

David Neumark, M. S. (2004). Minimum Wage Effects throughout the Wage Distribution. The Journal of Human Resources, 425-450.

Hennigusnia. (2014). Kesenjangan Upah Antarjender di Indonesia: Glass Ceiling atau Sticky Floor. Jurnal Kependudukan Indonesia, 83-96.

Hübler, O. (2005). Is There a Varying Unexplained Gender Wage Gap in Germany? Applied Economics Quarterly, 1-20.

International Labour Organization. (2018). Global Wage Report 2018/19: What lies behind gender pay gaps. Geneva: International Labour Organization.

International Labour Organization. (2020, October 6). International Labour Organization. Retrieved from Labour statistics on women: https://ilostat.ilo.org/topics/wome $\mathrm{n} /$

International Labour Organization. (2020, October 7). International Labour Organization. Retrieved from Introduction to International Labour Standards:

https://www.ilo.org/global/standa rds/lang--en/index.htm

Jacobs, J. C. (1998). Gender, the Welfare State, and Public Employment: A Comparative Study of Seven Industrialized Countries. American Sociological Review, 688-710. 
Kahn, F. D. (2000). Gender Differences in Pay. The Journal of Economic Perspectives, 75-99. Retrieved from http://www.jstor.com/stable/26470 76

Kumari, B. R. (2001). Work and Gender: A European Perspective. Economic and Political Weekly, 3603-3605.

Martesa Husna Laili, \&. A. (2019). Kesenjangan Upah Antargender di Indonesia: Bukti Empiris di Sektor Manufaktur. Jurnal Ekonomi dan Pembangunan Indonesia, 1-21.

Mendoze, E. N. (2017). Can Women's Organizations Work with the Patriarchal State? Philippine Sociological Review, 121-147.

Miranda, A. (2018). English Deficiency and the Native-Immigrant Wage Gap in the UK. London: University of London.

Moser, C. (2012). Mainstreaming Women's Safety in Cities into Gender-Based Policy and Programmes. Gender and Development, 435-452.

Naafs, S. (2013). Youth, Gender, and the Workplace: Shifting Opportunities and Aspirations in anIndonesian Industrial Town. The Annals of the American Academy of Political and Social Science, 233-250.

Napari, A. K. (2015). Gender Differences in Careers. Annals of Economics and Statistics, Special Issue on the Economics of Gender, No. 117/118, 6188. Retrieved from https://www.jstor.org/stable/10.15 609/annaeconstat2009.117-118.61

OECD. (2020, June 24). OECD.Stat. Retrieved from OECD.Stat: https://stats.oecd.org/
Pratomo, C. M. (2018). Labour Market Developments in the Jokowi Years. Journal of Southeast Asian Economies, 165-184.

Tadjoeddin, M. Z. (2014). Decent Work: On the Quality of Employment in Indonesia. Brill, 9-44.

The Economist. (2020, March 14). The Economist. Retrieved from Why the pay gap in Germany is so large: https://www.economist.com/europ e/2020/03/14/why-the-pay-gap-ingermany-is-so-large

Warburton, E. (2018). Inequality, Nationalism, and Electoral Politics in Indonesia. Yusof Ishak Institute, 135152.

Weintraub, S. (1956). A Macroeconomic Approach to the Theory of Wages. The American Economic Review, 835856.

Wiji Arulampalam, A. L. (2007, January). Is There a Glass Ceiling over Europe? Exploring the Gender Pay Gap across the Wage Distribution. ILR Review, 60, 163-186. Retrieved from http://www.jstor.com/stable/25249 069

Winfried Koeniger, M. L. (2007). Labor Market Institutions and Wage Inequality. ILR Review, 60, 340-356. Retrieved from https://www.jstor.org/stable/2524 9090

World Bank. (2020, June 24). World Development Indicators. Retrieved from World Development Indicators:

https://databank.worldbank.org/so 
Jurnal Hawa Vol. 2 No. 2 Juli-Desember 2020

urce/world-developmentindicators\#

203 | 」чгாа| Hawa 